\title{
Structural refurbishment of pavilions 15 and 16 of the Madrid slaughterhouse
}

\author{
J. Rey-Rey \\ Mecanismo Ingeniería, Universidad Politécnica de Madrid, Spain
}

\begin{abstract}
The Matadero Madrid cultural center is located in an old slaughterhouse and livestock market built between 1908 and 1928 in the Arganzuela district. The project was designed by architect Luis Bellido and it was structured around a number of pavilions with various purposes and services, covering a surface area of approximately $165,000 \mathrm{~m}^{2}$. The complex was characterized by its constructive rationality and conceptual simplicity, however it also incorporates some $\mathrm{NeO}$ Mudejar features. With the arrival of the new century, an important set of interventions were initiated by Madrid City Council in order to transform the space into a cultural hub. Thus, it became a place of new architectural experimentation, following the criteria of the Special Plan which focused on conservation and reversibility, allowing the buildings to be reconverted into their original states.

This paper describes the structural restoration of pavilions 15 and 16 for their new uses. These two pavilions, restored between 2009 and 2011, are twin pavilions in terms of structure (brick wall perimeter and steel columns and trusses interior) and volumetry. Pavilion no. 15 was transformed by Langarita-Navarro Architects and became the new "Music Pavilion" now hosting the Red Bull Music Academy headquarters in Madrid. Pavilion no. 16 was transformed into a new cultural and contemporary multi-functional space (concert hall, exhibition space, conference room, etc.) by ICA Architects.

Mecanismo Ingeniería undertook the structural refurbishment - including the micropile underpinning of the existing foundations - of both pavilions, which have received numerous international architectural awards including the Mies Van der Rohe 2013 mention, a FAD 2012 award, the AR+D for Emerging Architecture 2012 award, XII Spanish Biennale for Architecture Prize finalist and Arquia Próxima 2012 selected (no. 15) and FAD 2012 and COAM 2012 awards (no. 16). Keywords: Matadero Madrid, structural refurbishment, micropile underpinning, conservation, reversibility.
\end{abstract}




\section{Introduction}

The Matadero Madrid cultural center is located in an old slaughterhouse and livestock market built between 1908 and 1928 in the Arganzuela district [1]. The project was designed by architect Luis Bellido and it was structured around a number of pavilions with different purposes and services, covering a surface of approximately $165,000 \mathrm{~m}^{2}$ (Figure 1). The complex was characterized by its constructive rationality and conceptual simplicity, however it also incorporates some Neo-Mudejar features (Figure 2). With the arrival of the new century, an important set of interventions were initiated by Madrid City Council [2] in order to transform the space into a cultural hub. Thus, it became a place of new architectural experimentation, following the criteria of the Special Plan which focused on conservation and reversibility, allowing the buildings to be easily reconverted into their original states [3].

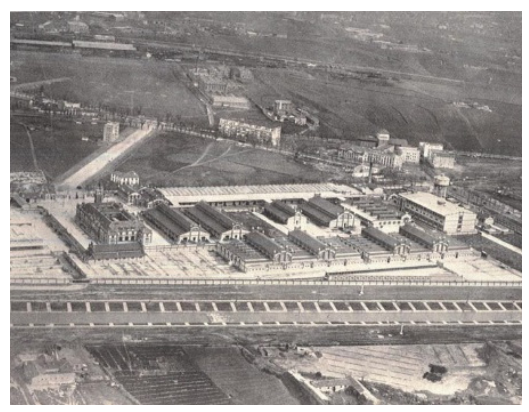

Figure 1: General view of Madrid's slaughterhouse - a photo of the period.

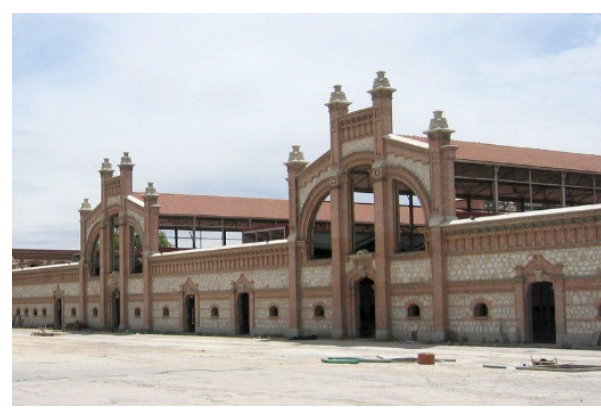

Figure 2: The main façade of pavilion 15 in its original state.

\section{Refurbishment of the original structure of the pavilions}

Pavilions 15 and 16, restored between 2009 and 2011, are twin pavilions in terms of structure (brick wall perimeter and interior steel columns and trusses) and volumetry [4] (Figures 3 and 4).

On the perimetral load bearing walls various structural pathologies were detected (Figure 5), consisting of the presence of fissures and cracks in some bricks which denoted the existence of a problem arising from excessive settlement of the wall foundations. This fact was corroborated by the performance of campaign tests on the existing foundations as well as a geotechnical study.

According to the campaign tests performed on site, the depth reached by the foundation is approximately $2.50 \mathrm{~m}$ in relation to the natural terrain elevation, being embedded in all cases inspected at geotechnical level 1, (quaternary sands). The geotechnical study on pavilion 16 was performed by LCC with reference 

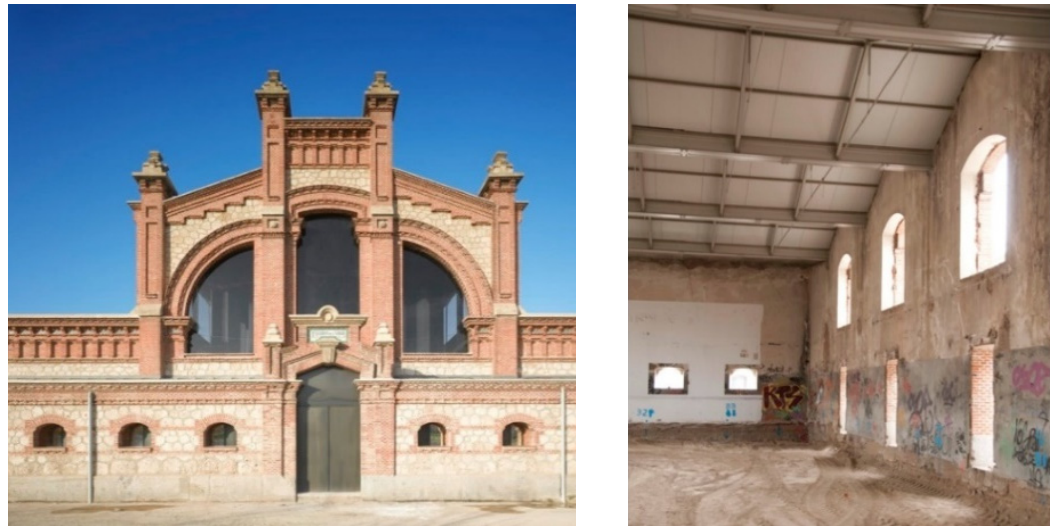

Figure 3: Pavilion 15 (exterior view). Figure 4: Pavilion 15 (interior view).
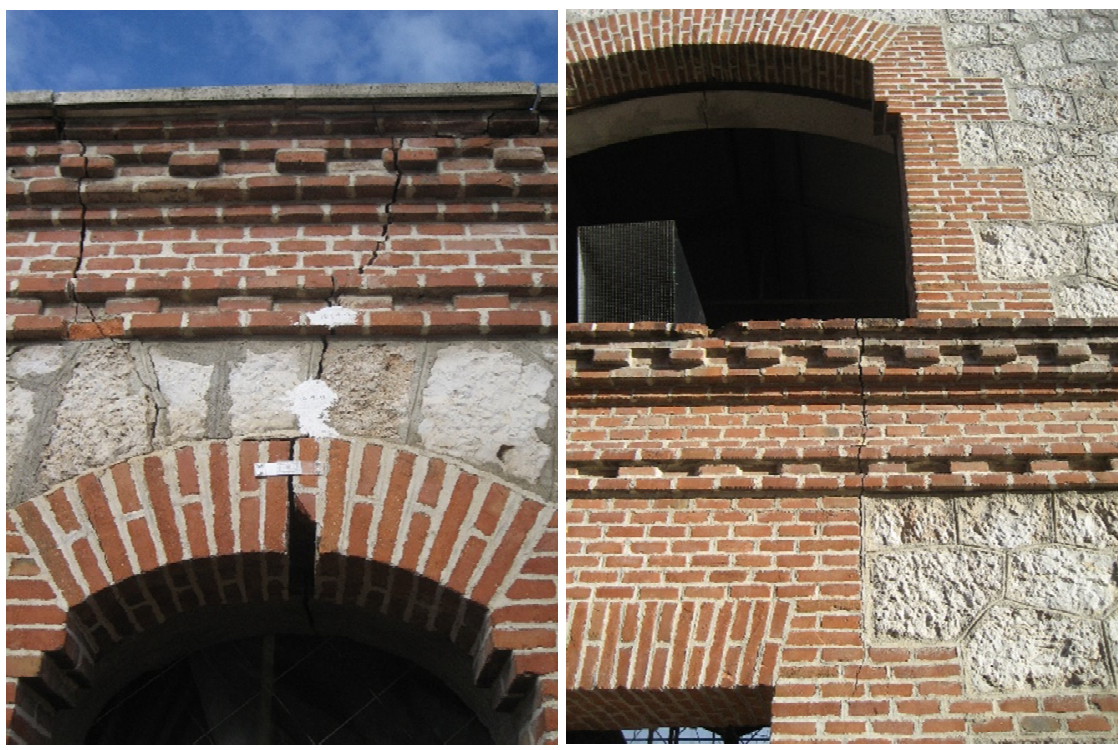

Figure 5: Images of some of the existing cracks on the façade load bearing walls.

3/6803/016 [5] and established an allowable bearing pressure for that geotechnical level 1: $\mathrm{q}_{\mathrm{adm}} \approx 0.40 \mathrm{Kp} / \mathrm{cm}^{2}$, a value which is considered very low, thus confirming the origin of the pathologies observed on the load bearing walls. GMC Ingeniería undertook the geotechnical study of pavilion 15, with reference EG-2916/13 [6], confirming this hypothesis. 
Considering the poor mechanical properties of the soil at the base of the existing foundations underpinning was required, ensuring embedment in geotechnical level 2 (miocene clays), which guaranteed a consistency and continuity suitable for receiving loads from the foundations.

Thus, the existing walls were stabilized by providing new pile caps annexed to both wall faces and joined together by means of prestressed steel bars (Figure 6). Pile caps rest on $150 \mathrm{~mm}$ diameter micropiles designed to withstand a load of 25 tons each and that rest on the so-called geotechnical level 2 (miocene clays).
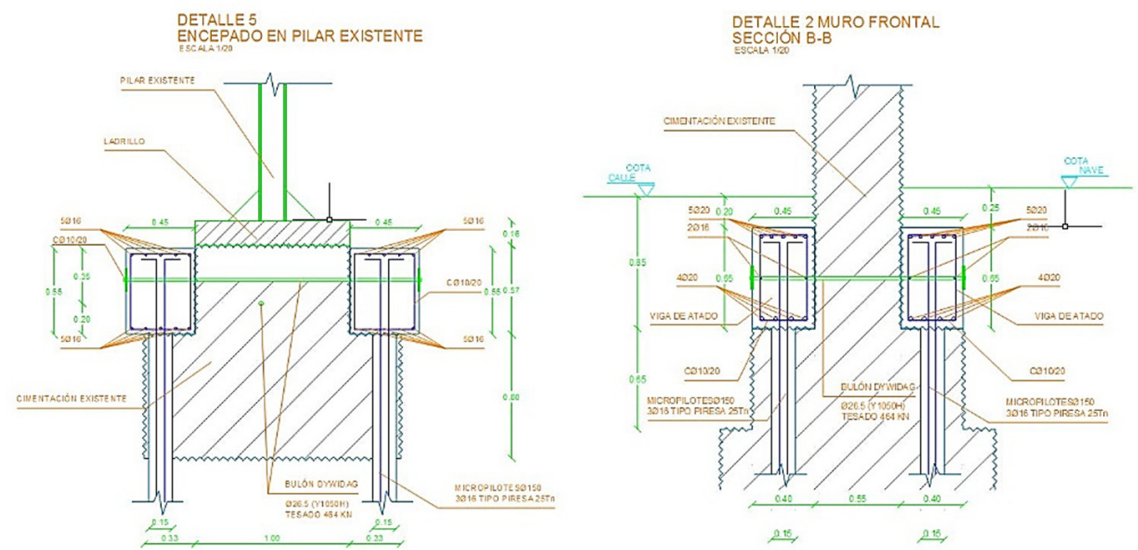

Figure 6: Underpinning of existing foundations (cross sections, detail).

An analysis of the load bearing capacity of the existing steel structure (Figure 7) was performed to assess the need for possible strengthening by a threedimensional calculation model developed on Autodesk Robot v2009 (Figure 8), which concluded that this hypothetical refurbishment was not necessary.
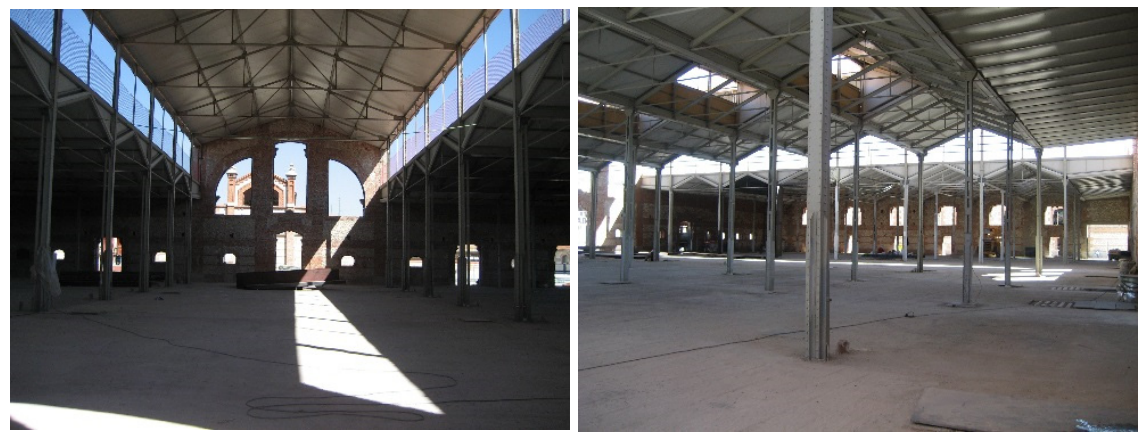

Figure 7: Interior views of the original state of pavilions 15 and 16. 


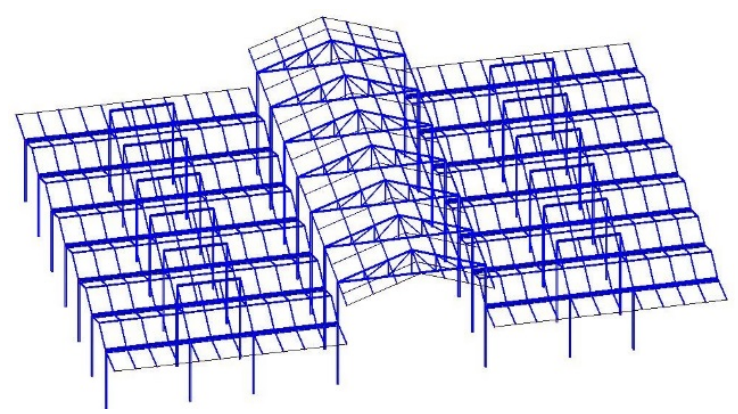

Figure 8: Calculation model of the existing steel structure.

This calculation model also helped to identify possible allowable load patterns (Figure 9) on the existing trusses in view of the future building operating (hanging ornamental elements, art works, lighting fixtures, etc.).
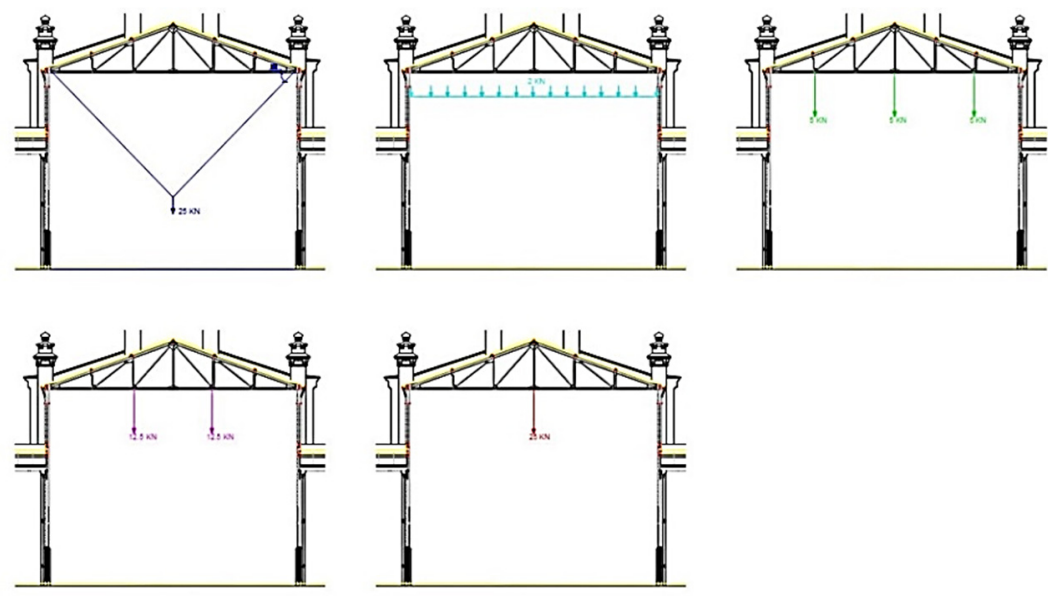

Figure 9: Allowable load patters on existing steel trusses.

The underpinning of the foundation of the existing walls also allowed for the design of a series of underground galleries which allowed the location of the general facilities of the buildings and even indoor-outdoor connections below the foundations of the existing walls.

\section{New structures}

With the arrival of the new century, an important series of interventions were undertaken by Madrid City Council in order to transform the space into a cultural hub. Thus, it became a place of new architectural experimentation, following the criteria of the Special Plan which focused on conservation and reversibility, allowing the buildings to be easily reconverted into their original states. 
Pavilion no. 15 was transformed by Langarita-Navarro Architects and became the new "Music Pavilion" now hosting the Red Bull Music Academy headquarters in Madrid. Pavilion no. 16 was transformed into a new cultural and contemporary multi-functional space (concert hall, exhibition space, conference room, etc.) by ICA Architects.

Mecanismo Ingeniería undertook the structural refurbishment - including the micropile underpinning of the existing foundations - of both pavilions, which have received numerous international architectural awards.

\subsection{Pavilion 15: Red Bull Music Academy}

The Red Bull Music Academy is a nomadic annual music festival held every year in a different city around the world. The 2011 edition was meant to be held in Tokyo but due to the effects of the serious earthquake that affected the Fukushima nuclear plant, Red Bull decided to change the location [7]. Madrid was chosen as the new city, so in only five months a project had to be undertaken in pavilion 15 of Matadero Madrid. This project is known as Nave de Música.

At that point pavilion 15 was an open space of approximately $4,700 \mathrm{~m}^{2}$ comprising of an interior steel structure (columns, trusses and joists) and a perimetral brick wall. Mainly due to the lack of time to carry out complex interventions in the existing building the decision was taken not to modify in any way the original structure, so the program organization (which included offices, studios for musicians, conference area, radio, recording studios, etc.) was located in new light envelopes (Figure 10) inside the container (thereby taking into consideration the temporary nature of the project and trying to avoid any influence on future interventions in the building, enhancing the reversibility of the intervention: for instance by the use of sandbags to build the walls of the recording studio) [8].

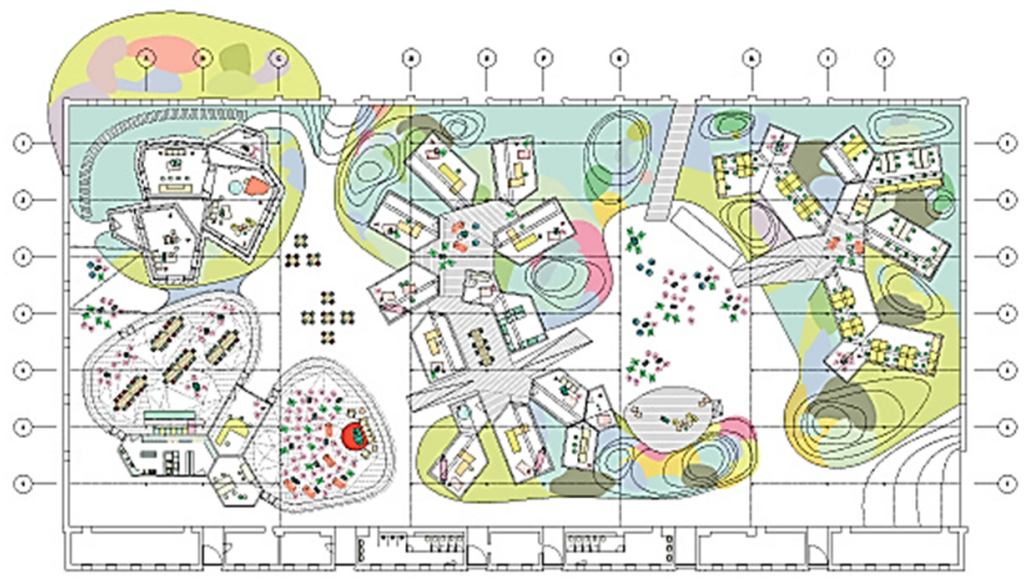

Figure 10: Plan view. General arrangement of the new constructions inside the existing pavilion. 
The interior containers were solved with light steel structures. These structures were designed with bolted connections in order to shorten assembly times and also to enable the reversibility of the proposal (Figure 11).
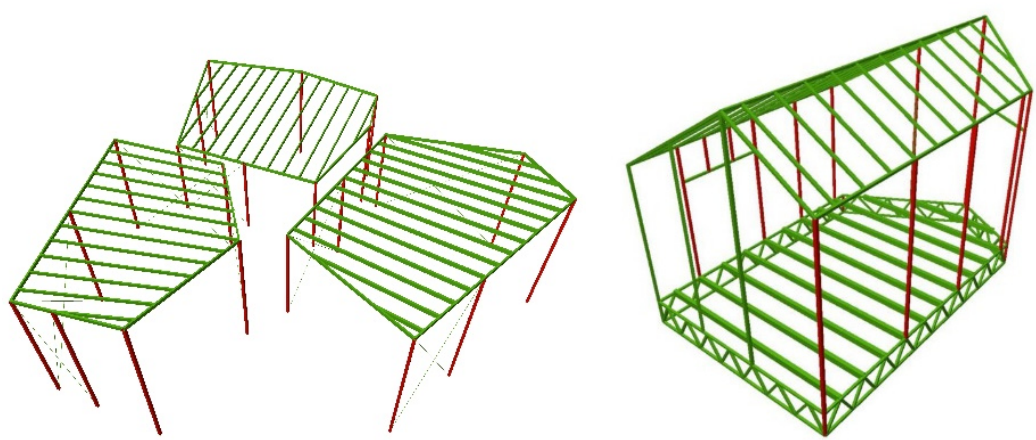

Figure 11: Calculation model views of some of the interior structures.

Some special pieces have also been designed with bolted steel structures with the peculiarity is that the roofs of such containers are hang from the trusses of the existing structure by steel ties.
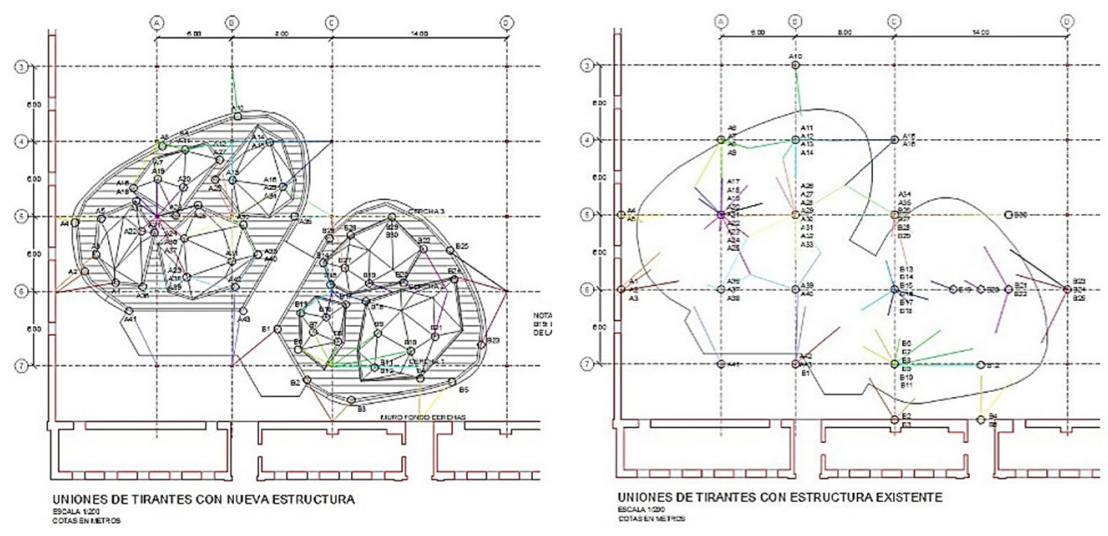

Figure 12: Hanging steel structure (schematic plan views).

For the structural and geometrical analysis of such roof structures supported by the existing trusses with steel ties, a three-dimensional calculation model in Autodesk Robot v2009 (Figure 13) was carried out. The fact of hanging the roofs made it possible to have wide open spaces without internal supports in these areas (Figure 14).

Inside the pavilion, the abundance of vegetation stands out, along with new boxes designed to accommodate the various different new uses required: recording studio, radio, etc. (Figure 15). 


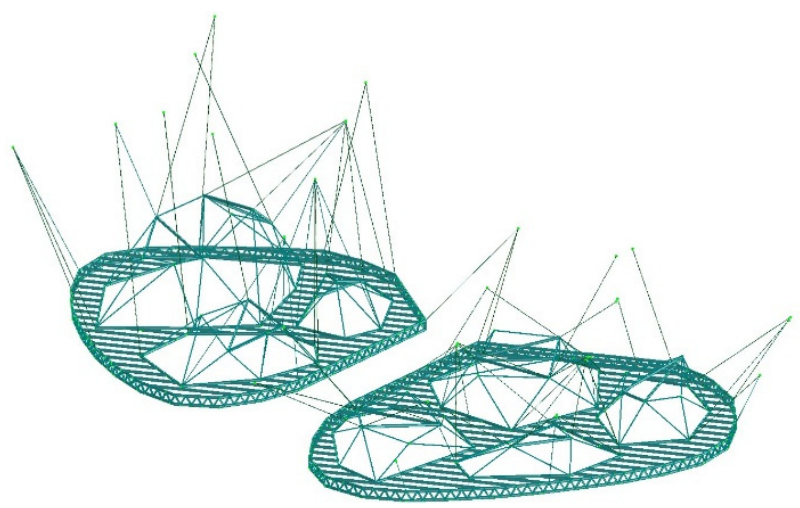

Figure 13: New hanging steel structures from the existing structure of pavilion 15 - calculation 3D model.

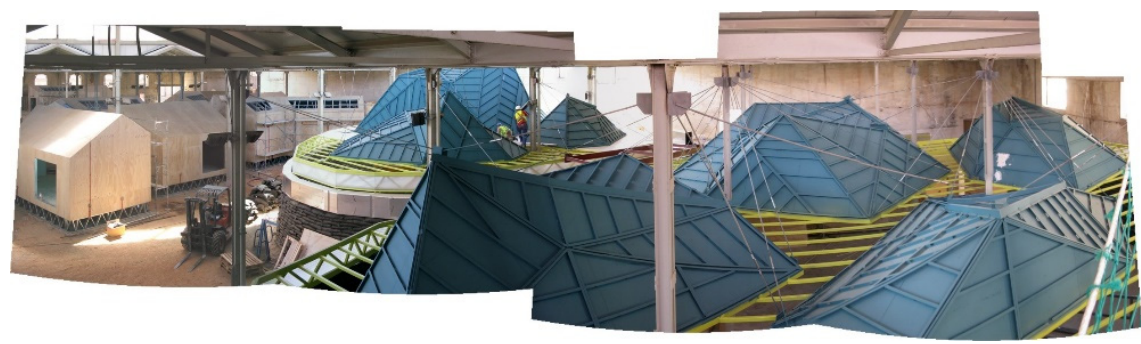

Figure 14: New hanging steel structures from the existing structure of pavilion 15 - built structures.

\subsection{Pavilion 16}

In this case the goal was to reuse pavilion 16 (the twin building of pavilion 15) as a new cultural center and contemporary multifunctional space. Depending on the needs of the moment, the space might be used as a concert hall, exhibition hall, conference room or even fashion catwalk. A mobile system that transformed the space according to the required program was requested: a versatile exhibition hall that can function as the largest exhibition hall in Madrid or as a set of spaces for smaller independent exhibitions.

Iñaqui Carnicero, one of the architects who along with Alejandro Vírseda and Ignacio Vila (ICA Arquitectos) won the public competition held in 2007 explained the aim of the intervention: "Given a limiting budget, we reduced our architectural decisions into two unique actions. The first one uses a particular industrial element: doors. By manipulating their position, the functional possibilities of the design were multiplied. For example, the main space could be transformed into smaller spaces to celebrate different activities simultaneously. The second move 

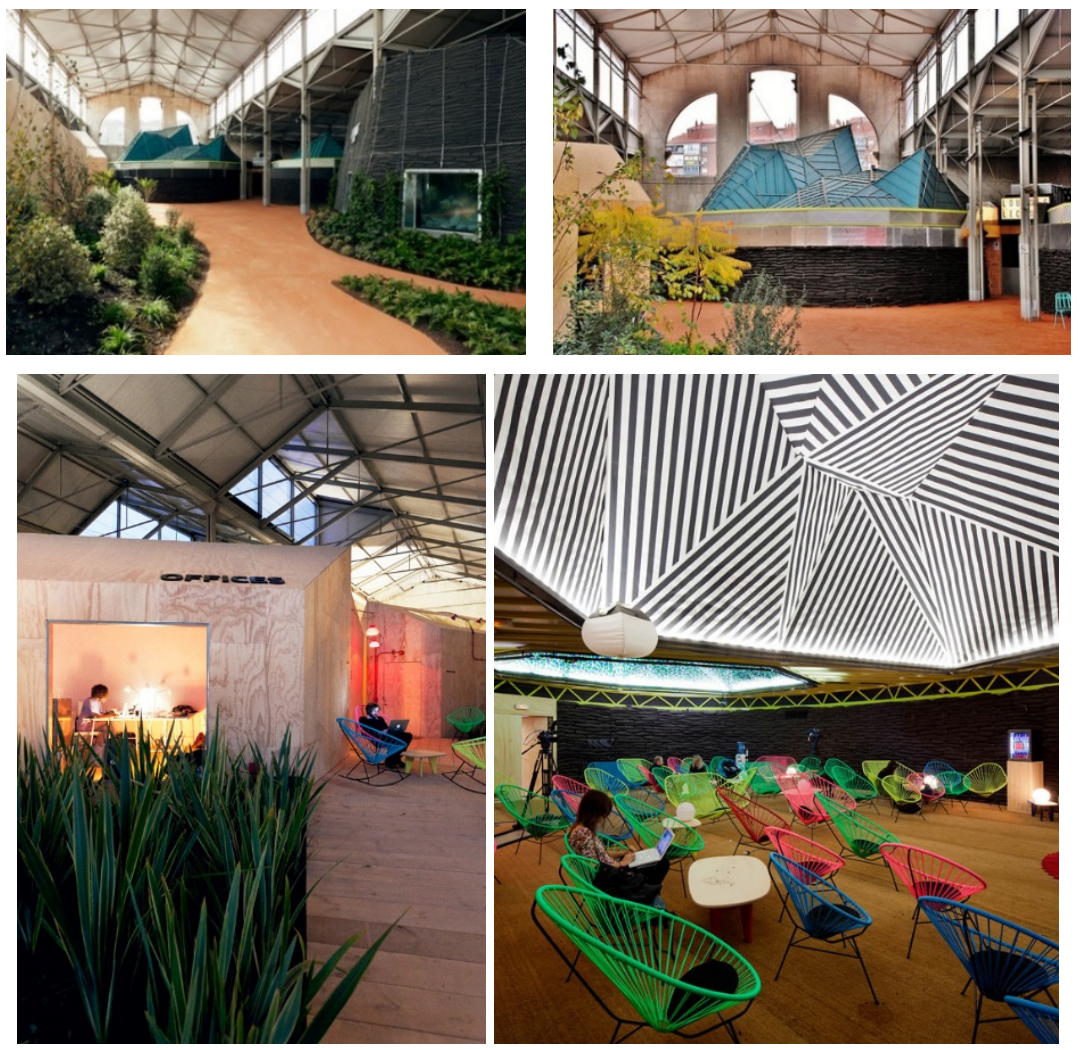

Figure 15: Interior views of the current state of pavilion 15.

was to recover the brickwork to establish a distinct atmosphere within the building. The execution of these two simple ideas reinforced the scale and proportions of the interior, while at the same time, it revamped the character of the building" [9]. The adaptable intervention is based on a system of double-height, pivoted steel doors that can be easily adjusted to meet the needs of the user (Figure 16(a)).

To support the new windows and doors situated on the main hall, a new steel structure was designed (Figures 16(b) and 16(c)). New steel members were welded in continuity to the existing IPN 240 steel profiles. Over these elements a new steel beam was placed to support the windows. In the area of greatest span (both ends of the pavilion) this structure was hung from the existing structure. That implied strengthening the existing trusses and foundations in this area.

It should be noted that the construction of a large services gallery attached to the south façade of the existing pavilion was designed with a perimeter diaphragm wall of reinforced concrete piles and flat reinforced concrete slabs both on foundation and roof levels.

The outcome is a simple, reversible intervention that allows great flexibility of use to the existing building, making it one of the largest exhibition spaces currently available in Madrid (Figure 17). 


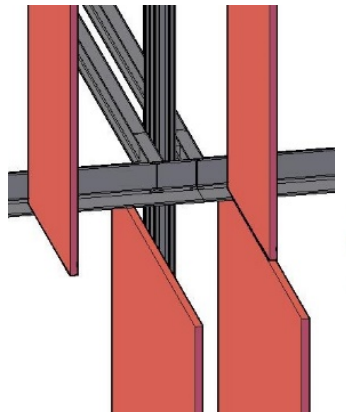

(a)

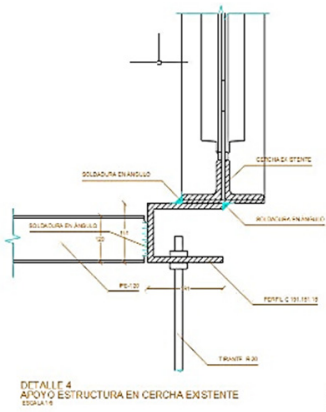

(b)

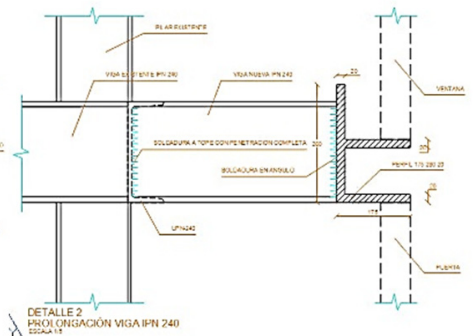

(c)

Figure 16: New steel structures to support the new doors and windows. (a) geometry; (b) and (c) details of structure.
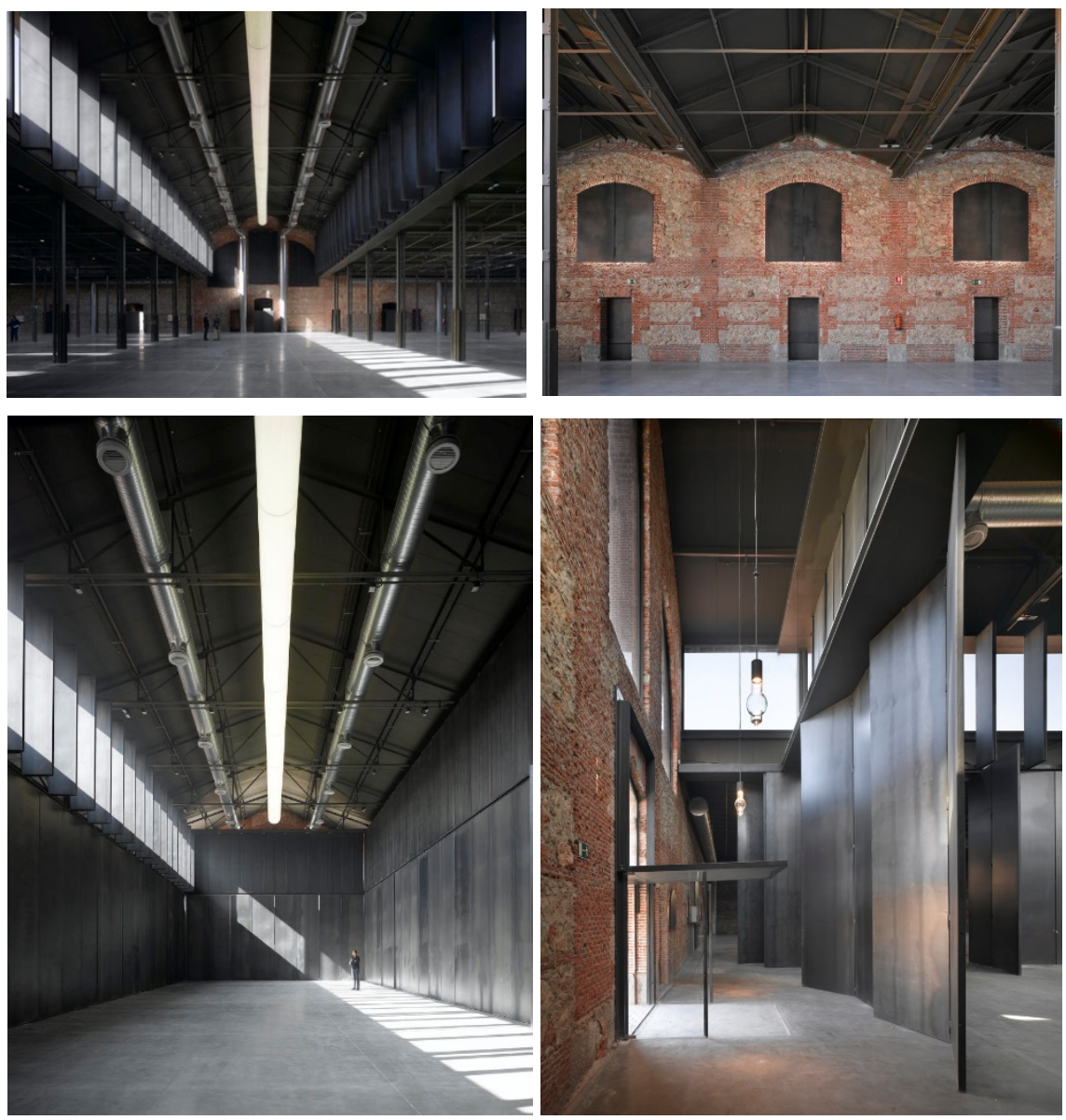

Figure 17: Interior views of the current state of pavilion 16. 


\section{Conclusions}

The paper focuses on the structural refurbishment carried out in twin pavilions 15 and 16 of the old Madrid slaughterhouse, one of the most important sites of industrial architectural heritage in the city of Madrid.

In both cases the proposals enhance the conservation of existing architectures and the reversibility of the new actions necessary to accommodate the new required uses: pavilion 15 was transformed by Langarita-Navarro Architects into the new "Music Pavilion" and is the current headquarters for the Red Bull Music Academy in Madrid; pavilion 16 was transformed into a new cultural and contemporary multi-functional space (concert hall, exhibition space, conference room, etc.) by ICA Architects.

Mecanismo Ingeniería undertook the structural refurbishment - including the micropile underpinning of the existing foundations - of both pavilions, which have received numerous international architectural awards.

\section{Acknowledgements}

The author wishes to thank the entire team of Mecanismo Ingeniería (especially Jacinto Ruiz Carmona, Pablo Vegas González, Rinske Daniels and Nuria Aranda García), as well as all the other professionals and companies involved in the design and construction of both buildings.

The most relevant data is summarized in Table 1.

Table 1: Credits.

\begin{tabular}{|l|l|l|}
\hline Building & Matadero Pavilion 15 & Matadero Pavilion 16 \\
\hline Site & Paseo de la Chopera (Madrid) & Paseo de la Chopera (Madrid) \\
\hline Date & $2010-2011$ & $2010-2012$ \\
\hline $\begin{array}{l}\text { Total Floor } \\
\text { Area }\end{array}$ & $4,700 \mathrm{~m}^{2}$ & $5,913 \mathrm{~m}^{2}$ \\
\hline Budget & $1,428,100.50 €$ & $5,970,286.14 €$ \\
\hline Architects & Langarita-Navarro Arquitectos & $\begin{array}{l}\text { Ignacio Vila Almazán } \\
\text { Alejandro Vírseda Aizpún } \\
\text { Iñaqui Carnicero }\end{array}$ \\
\hline Client & Private & $\begin{array}{l}\text { Área de Gobierno de las Artes } \\
\text { del Ayuntamiento de Madrid }\end{array}$ \\
\hline $\begin{array}{l}\text { Building } \\
\text { Engineers }\end{array}$ & Javier Reñones & Manuel Iglesias Velasco \\
\hline $\begin{array}{l}\text { Services } \\
\text { Engineers }\end{array}$ & Úrculo Ingenieros & J. G. Ingenieros Consultores \\
\hline $\begin{array}{l}\text { Structural } \\
\text { Engineers }\end{array}$ & Mecanismo Ingeniería & Mecanismo Ingeniería \\
\hline Contractor & Vías y Construcciones & Vías y Construcciones \\
\hline
\end{tabular}


Table 1: Continued.

\begin{tabular}{|l|l|l|}
\hline \multirow{5}{*}{ Awards } & $\begin{array}{l}\text { AR+D Award for emerging } \\
\text { architecture 2012, } \\
\text { FAD Award 2012 (First prize), } \\
\text { XII Bienal Española de } \\
\text { Arquitectura y Urbanismo 2013 } \\
\text { (Finalist), }\end{array}$ & $\begin{array}{l}\text { AR+D Award for emerging } \\
\text { architecture 2011 (Highly } \\
\text { commended), } \\
\text { (Selected) } \\
\text { (Selaia-Próxima 2012 Award } \\
\text { European Union Prize for } \\
\text { Contemporary Architecture } \\
\text { Mies van der Rohe Award 2013 } \\
\text { (special mention - emergent } \\
\text { architects) }\end{array}$ \\
\hline
\end{tabular}

\section{References}

[1] Lasso de la Vega, M., Memoria histórica del antiguo Matadero Municipal de Madrid, Servicio histórico del COAM: Madrid, 2005.

[2] Matadero Madrid. New times, new architecture. Last accessed 10 Mar 2015. http://www.mataderomadrid.org/new-times-new-architecture.html

[3] Ayuntamiento de Madrid, Concejalía de las Artes, La arquitectura de Matadero Madrid. Matadero Madrid: Madrid, 2012.

[4] CEDEX, Inspección y caracterización de los materiales de varios edificios del antiguo matadero de Legazpi, CEDEX: Madrid, 13-506-2-001, 2006.

[5] LCC, Caracterización de estructura y cimentación de la nave 16 del matadero de Madrid, LCC: Madrid, 3/6803/016, 2010.

[6] GMC Ingeniería, Estudio geotécnico de la nave 15 de Matadero de Madrid, GMC: Madrid, EG-2916/13, 2014.

[7] Red Bull Music Academy. Nave de la Música en Matadero Madrid. Last accessed 10 Mar 2015. http://www.langarita-navarro.com/eng/project/redbull-music-academy/

[8] Langarita Navarro. 2G, no. 70, Ed. Gustavo Gili: Barcelona, 2015.

[9] Hangar 16 Matadero Madrid. Last accessed 10 Mar 2015. http://www.inaquicarnicero.com/Hangar-16-Matadero-Madrid 